\title{
Clinical leadership in paramedic services: a narrative synthesis
}

\author{
Peter O'Meara \\ School of Rural Health, La Trobe University, Bendigo, Australia \\ Gary Wingrove \\ Mayo Clinic Medical Transport, Rochester, Minnesota, USA, and \\ Michael Nolan \\ Paramedic Services, County of Renfrew, Pembroke, Canada
}

\begin{abstract}
Purpose - In North America, delegated practice "medical direction" models are often used as a proxy for clinical quality and safety in paramedic services. Other developed countries favor a combination of professional regulatory boards and clinical governance frameworks that feature paramedics taking lead clinician roles. The purpose of this paper is to bring together the evidence for medical direction and clinical governance in paramedic services through the prism of paramedic self-regulation.

Design/methodology/approach - This narrative synthesis critically examines the long-established North American Emergency Medical Services medical direction model and makes some comparisons with the UK inspired clinical governance approaches that are used to monitor and manage the quality and safety in several other Anglo-American paramedic services. The databases searched were CINAHL and Medline, with Google Scholar used to capture further publications.

Findings - Synthesis of the peer-reviewed literature found little high quality evidence supporting the effectiveness of medical direction. The literature on clinical governance within paramedic services described a systems approach with shared responsibility for quality and safety. Contemporary paramedic clinical leadership papers in developed countries focus on paramedic professionalization and the self-regulation of paramedics.

Originality/value - The lack of strong evidence supporting medical direction of the paramedic profession in developed countries challenges the North American model of paramedics practicing as a companion profession to medicine under delegated practice model. This model is inconsistent with the international vision of paramedicine as an autonomous, self-regulated health profession.
\end{abstract}

Keywords Evidence-based practice, Clinical governance, Clinical leadership and culture

Paper type Literature review

\section{Introduction}

Quality, safety and professional accountability are central to the operation of all health and medical services (O'Hara et al., 2012; Freeman et al., 2016). This tenet is no less true for paramedic services even though differences in funding sources and regulatory regimes, education and certification requirements separate them from their respective health systems. They almost universally have historic roots in the military, voluntary organizations or the emergency services sector that continue to strongly influence paramedicine (Reynolds, 2009).

This narrative synthesis examines the quality and safety approaches of paramedic services adopted in the Anglo-American ambulance or emergency medical service (EMS) model that uses paramedics to staff ambulances as a distinct occupational group (Al-Shaqsi, 2010; Timmermanna et al., 2008). Within this model, there are variations in how paramedic services

(C) Peter O'Meara, Gary Wingrove and Michael Nolan. Published by Emerald Publishing Limited. This article is published under the Creative Commons Attribution (CC BY 4.0) licence. Anyone may reproduce, distribute, translate and create derivative works of this article (for both commercial \& non-commercial purposes), subject to full attribution to the original publication and authors. The full terms of this licence may be seen at http://creativecommons.org/licences/by/4.0/legalcode

\section{Clinical leadership in paramedic services}


IJHG

22,4

are funded, structured and managed; including the leadership and management of the quality and safety of clinical services. In the USA and much of Canada the delegated practice "medical direction" model is used as a proxy for optimal patient outcomes in paramedic service delivery (Garza and Mitchell, 2012; Fitzgerald, 2014; Becknell, 1997), while in contrast countries such as the UK, Ireland, Australia and New Zealand use an emerging combination of professional regulatory boards and clinical governance systems to manage quality and safety (Halligan and Donaldson, 2001; Ambulance Tasmania, 2012; Colbeck, 2014; Bury, 2005).

In the USA, medical oversight is considered to be a fundamental component of every EMSs system; the dominant argument is that "The quality of physician medical direction has a significant impact upon the system and patient outcome" (Cunningham et al., 2010). This view is enshrined in key US EMS policy documents and legislation, and is deeply embedded into emergency medical technician and paramedic curricula (US National Highway Traffic Safety Administration, 1996; National Rural Health Association, 1997; Michael and French, 2000; US Congress, 2016). An example of this position is found in an EMS Medical Directors Handbook that argues that "[...] the medical director should have ultimate authority over all clinical and patient care aspects of the EMS agency [...] including the authorization to limit immediately the patient care activities of those who deviate from established standards or do not meet training standards." (Garza and Mitchell, 2012) Across the USA, paramedics obtain certification or licensure through a department or office located within their State government structure. Even after this certification, paramedics are unable to function unless under the supervision of a licensed paramedic service and under the delegated medical practice of a physician medical director. The medical director is responsible for patient care activities performed by paramedics, taking responsibility for their appropriateness, and that these activities are within their scope of practice and operational expectations (Garza and Mitchell, 2012; Bass et al., 2015):

Physicians have advocated that physician medical direction, regardless of other design features, will produce reliable response times and quality. However, if systems with physicians in direct control of operations do not always produce reliable response times or safe policies this could lead decision makers to consider other design features in order to ensure quality. While effective medical direction may be essential to a well performing system, the presence of physicians in management roles in the absence of other critical features may not guarantee reliable response time performance or quality (Dean, 2004; p. 19).

The view that medical oversight and direction are essential to the operation of paramedic services is not universally accepted, with some high-performing paramedic services operating without any legal or regulatory requirement to involve the medical profession in their operation and management (Eburn, 2014; Colbeck, 2014). Likewise, the accreditation of educational programs and the certification of individual paramedics to practice in many developed countries is the responsibility of either paramedic services that issue certificates to practice or professional regulatory boards under the control of the State or the paramedic profession (Eburn and Bendall, 2010; Council of Ambulance Authorities, 2010; Health and Care Professions Council, 2015). In contrast to the USA and much of Canada, the role of physician medical directors in other developed countries is not central to the operation of paramedic services. Medical officers tend to be employed as expert advisors, rather than necessarily exercising direct executive authority over the management of the paramedic service in the North American sense (Wilkes, 2010; O'Meara et al., 2001).

Clinical governance is a more recent governance model that is widely deployed in the UK and other countries with similar health system structures. It emerged during the mid-1990s following a number of high profile cases documenting systems failures and poor health care quality standards that emerged within the UK National Health Service (NHS). A high profile example of this was the "Bristol Case" where there was a large systems failure and the standard of care given was below the acceptable level for the health professionals concerned 
(Brennan and Flynn, 2013). Since its implementation and refinement, clinical governance has become an important framework that encourages autonomy and accountability within various types of health care organizations, including paramedic services (Ambulance Service of New South Wales, 2015; Ambulance Tasmania, 2012; Robertson-Steel et al., 2000). For instance, in all Australian states and territories, clinical governance structures are mandated for health services and hospitals (Spigelman and Rendalls, 2015).

The aim of this narrative synthesis was to critically examine the long-established North American medical direction model and make some comparisons with the more recent UK inspired clinical governance approaches that are used to monitor and manage the quality and safety in other Anglo-American paramedicine services. In the literature, their respective elements, strengths and weakness are described, with the narrative synthesis considering how each approach to the management of clinical quality and safety might inform the other. Exploration of international efforts to professionalize paramedicine and move toward forms of autonomous practice and professional self-regulation provide a contemporary paramedicine context.

\section{Methods}

The research approach sought to find and assess the available evidence related to these two approaches to the management of quality and safety of paramedic services and paramedic practice, and to gain an appreciation of the contextual factors that have resulted in different quality and safety systems evolving in broadly similar paramedic services.

Searches of the peer-reviewed literature relating to medical direction and clinical governance in paramedic services and paramedic practice took place using CINAHL and Medline. They were the most likely databases to list relevant articles, with Google Scholar used to capture a broader range of publications in a less systematic manner. Search terms were medical direction, medical oversight, clinical governance and quality assurance; with each then combined with EMS, paramedic*, or ambulance. A further search combining clinical leadership and paramedic* was employed following preliminary analysis of the data. The search was limited to English-language sources since 2000 to reflect the relatively recent development of professional paramedic education and scholarship, as well as the widespread emergence of paramedic roles involving high-level clinical interventions. Examination of the reference lists of identified studies produced additional papers.

A process of narrative synthesis provided a summary of the current state of knowledge and located a critique within the question of clinical leadership and the self-regulation of paramedic practice within the Anglo-American paramedicine model (Popay et al., 2005). This methodological approach has been used elsewhere in health services research (Pretorius et al., 2015) and is well suited to examining the sometimes long established policies and practices which in this instance are variously described as medical direction, medical oversight, clinical governance, self-regulation and clinical leadership.

\section{Evidence from the literature}

The essential elements, strengths and weakness of medical direction and clinical governance are considered and how each approach to quality assurance might inform the other. Both approaches share the common motive of improving efforts to manage clinical quality and safety in paramedic services and paramedic practice. The scholarship surrounding contemporary paramedic professionalization and leadership facilitated critical analysis of the evidence for medical direction and clinical governance.

\section{Medical direction and clinical governance}

There is limited evidence in the peer-reviewed literature that empirically supports or refutes the effectiveness of medical direction. This is consistent with the findings of a recent

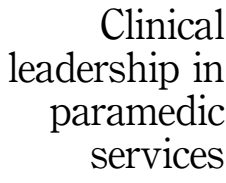

253 
IJHG

22,4

254

systematic review that highlighted "[...] the lack of evidence on effective safety governance strategies in emergency care settings, particularly in the field of prehospital emergency care" (p. 11) (Hesselink et al., 2016). Many of the identified articles identified in the review tended to argue how essential medical direction is without any firm rationale or recent empirical evidence to support the model. Typically, one non-refereed paper from the late1990s argued that "[It] [...] should be intuitive and logical that a qualified EMS physician would have a positive impact on prehospital emergency care" (Matera, 1997). In total, 26 papers met the inclusion criteria (Table I), 19 focused on EMS medical direction (mainly derived from the USA), while seven related to clinical governance in paramedic services. Despite two of the medical direction papers selected being non-refereed, they were included due to their relevance (Busko et al., 2006; Peterson, 2002).

Millin et al. (2011) provided a comprehensive literature review of EMS physician roles in the USA. There are few comparative studies available, with Munk's paper focusing on whether there was a relationship between medical direction and an improvement in EMS quality indicators (Munk et al., 2009). In a recent paper, Cushman et al. (2010) examined the effects of physician oversight of a prehospital rapid-sequence intubation program. While they concluded that close concurrent and retrospective physician oversight is associated with improved cognitive skills, they were not able to make a causal link. A much older paper was located that compared the impact of medical direction against a fire chief (Frank, 1984), however apart from being dated, this study has little meaning to those with no reference points for Fire/EMS systems. Modern paramedic services outside North America take for granted that paramedic services are paramedic-led with fire brigades providing basic life support first responder programs under the direct coordination and control of paramedic services (Stanley, 2014; Woollard, 2006).

Other papers focused on the availability, recruitment and retention of medical directors (Slifkin et al., 2009; O'Meara et al., 2001; Cone et al., 2014; Knott, 2003) and the quality or frequency of medical director involvement in EMS (Stone et al., 2000; Studnek et al., 2009; Busko et al., 2006). One US paper examined variability in the capacity and availability of medical directors to provide a field response in the out-of-hospital environment (Cone et al., 2000), while another examined tactical EMS medical direction (Tang and Fabbri, 2003). Related topics have been examined in the UK, partially in terms of medical officers seeking approval from NHS Ambulance Trusts to practice in the prehospital environment (Robertson-Steel et al., 2000; Porter, 2005). The two recent papers from South Korea illustrated the link between the need for medical direction and limited education amongst providers in under-developed EMS systems (Lee and Kim, 2015; Kim et al., 2015).

The remainder of the medical direction papers were guidelines for medical directors or commentaries on the value of medical direction (Barnett et al., 2006; Cunningham et al., 2010; Peterson, 2002; Gausche-Hill et al., 2003; Benitez and Pepe, 2002; Polsky et al., 1993). Peterson's short paper provides a clear illustration of how emergency physicians see out-of-hospital EMS fitting into a wider EMS system (Peterson, 2002). These papers are highly derivative from a small number of national position papers (Committee on the Future of Emergency Care in the United States Health System, 2007; Delbridge et al., 1998; National Research Council, Committee on Trauma and National Research Council, Committee on Shock, 1971) and a flood of opinion papers in either the emergency medicine literature or in non-refereed EMS journals from the late 1970s to the mid-1980s (Amey et al., 1978; Ferko, 1987; Frank, 1984; Golin, 1980; Henry and Stapleton, 1985; Newman, 1982), with the accepted position on medical direction restated with little change or critique since the first accounts in the 1970s. One group of non-refereed papers that stand out from the late1990s, provide an optimistic view of the legal and operational evolution of the medical director role in the USA, albeit perpetuating a paternalistic view that medical directors "take care of paramedics" (Becknell, 1997; Matera, 1997; Krohmer, 1997; Nicholson, 1997). 


\begin{tabular}{|c|c|c|c|c|c|}
\hline Citation & Design & Country & Focus of paper & $\begin{array}{l}\text { Major findings (strengths and } \\
\text { weaknesses) }\end{array}$ & leadership in \\
\hline \multirow[t]{2}{*}{$\begin{array}{l}\text { Cushman } \\
\text { et al. }(2010)\end{array}$} & \multirow[t]{2}{*}{$\begin{array}{l}\text { Retrospective } \\
\text { cohort }\end{array}$} & \multirow[t]{2}{*}{ USA } & \multirow[t]{2}{*}{ Rapid-sequence intubation } & \multirow{2}{*}{$\begin{array}{l}\text { Concluded that close concurrent } \\
\text { and retrospective physician } \\
\text { oversight is associated with } \\
\text { improved cognitive skills, } \\
\text { although the observed changes } \\
\text { were not causally linked to the } \\
\text { intervention }\end{array}$} & $\begin{array}{l}\text { paramealc } \\
\text { services }\end{array}$ \\
\hline & & & & & \\
\hline Lee and Kim & Surveys to & South & Recognition of medical direction & EMT-basics and first & \\
\hline (2015) & EMS personnel & Korea & $\begin{array}{l}\text { in EMS personnel according to } \\
\text { qualification level }\end{array}$ & $\begin{array}{l}\text { responders have higher need } \\
\text { for medical direction in an } \\
\text { under-developed EMS system }\end{array}$ & \\
\hline Kim et al. & Descriptive & South & Report on the process and results & "Patient evaluation" was the & \\
\hline (2015) & analysis & Korea & $\begin{array}{l}\text { of the newly implemented } \\
\text { medical direction system }\end{array}$ & $\begin{array}{l}\text { most common reason for } \\
\text { EMTs to request medical } \\
\text { direction }\end{array}$ & \\
\hline $\begin{array}{l}\text { Fitzgerald } \\
(2014)\end{array}$ & $\begin{array}{l}\text { Rhetorical } \\
\text { genre theory }\end{array}$ & Canada & $\begin{array}{l}\text { Challenges medical direction of } \\
\text { paramedics }\end{array}$ & $\begin{array}{l}\text { Hidden values and } \\
\text { assumptions (medical } \\
\text { dominance) have delayed the } \\
\text { adoption of a paramedic self- } \\
\text { regulation model in Ontario }\end{array}$ & \\
\hline $\begin{array}{l}\text { Millin et al. } \\
\text { (2011) }\end{array}$ & $\begin{array}{l}\text { Literature } \\
\text { review }\end{array}$ & USA & Physician roles in EMS & $\begin{array}{l}\text { Claimed that evidence for } \\
\text { medical direction is evolving. } \\
\text { Review of USA literature, } \\
\text { excluded other countries }\end{array}$ & \\
\hline $\begin{array}{l}\text { Nutbeam } \\
(2011)\end{array}$ & Commentary & UK & $\begin{array}{l}\text { Clinical governance for out-of- } \\
\text { hospital providers other than } \\
\text { paramedics }\end{array}$ & $\begin{array}{l}\text { Need for clinicians supporting } \\
\text { Ambulance Trusts to } \\
\text { participate in clinical } \\
\text { governance activities }\end{array}$ & \\
\hline $\begin{array}{l}\text { Cunningham } \\
\text { et al. }(2010)\end{array}$ & Commentary & USA & Benchmarking medical direction & $\begin{array}{l}\text { Limited snapshot of medical } \\
\text { direction }\end{array}$ & \\
\hline $\begin{array}{l}\text { Webb et al. } \\
(2010)\end{array}$ & Descriptive & UK & $\begin{array}{l}\text { Clinical governance in a } \\
\text { correctional institution where } \\
\text { doctors, nurses and paramedics } \\
\text { provide clinical care }\end{array}$ & $\begin{array}{l}\text { Risk management, with a } \\
\text { regular review of clinical } \\
\text { incidents is an essential part } \\
\text { of clinical governance }\end{array}$ & \\
\hline $\begin{array}{l}\text { Munk et al. } \\
\text { (2009) }\end{array}$ & $\begin{array}{l}\text { Comparative } \\
\text { study }\end{array}$ & USA & $\begin{array}{l}\text { Improvement in EMS quality } \\
\text { indicators }\end{array}$ & $\begin{array}{l}\text { Medical direction associated } \\
\text { with improved clinical } \\
\text { indicators and quality of care }\end{array}$ & \\
\hline $\begin{array}{l}\text { Slifkin et al. } \\
\text { (2009) }\end{array}$ & Survey & USA & $\begin{array}{l}\text { Assessment of rural-urban } \\
\text { differences in medical direction }\end{array}$ & $\begin{array}{l}\text { Recruitment of medical } \\
\text { directors is challenging in } \\
\text { rural areas }\end{array}$ & \\
\hline $\begin{array}{l}\text { Studnek et al. } \\
\text { (2009) }\end{array}$ & $\begin{array}{l}\text { Survey of EMS } \\
\text { professionals }\end{array}$ & USA & $\begin{array}{l}\text { Quantifies the amount of } \\
\text { direct contact between } \\
\text { EMS professionals and } \\
\text { medical directors }\end{array}$ & $\begin{array}{l}\text { One third of EMS providers } \\
\text { had limited medical director } \\
\text { contact }\end{array}$ & \\
\hline $\begin{array}{l}\text { Busko et al. } \\
(2006)\end{array}$ & Commentary & USA & $\begin{array}{l}\text { Examination of different models } \\
\text { of medical direction }\end{array}$ & $\begin{array}{l}\text { Medical direction has not } \\
\text { changed to reflect the needs of } \\
\text { modern EMS. Non-refereed }\end{array}$ & \\
\hline $\begin{array}{l}\text { Barnett et al. } \\
(2006)\end{array}$ & Commentary & $\begin{array}{l}\text { West } \\
\text { Indies }\end{array}$ & $\begin{array}{l}\text { Potential physician roles in the } \\
\text { Caribbean EMS system }\end{array}$ & Derivative document & \\
\hline $\begin{array}{l}\text { Mason et al. } \\
\text { (2006) }\end{array}$ & $\begin{array}{l}\text { Survey and } \\
\text { interviews }\end{array}$ & UK & $\begin{array}{l}\text { Describes the development of } \\
\text { Extended Care Practitioner } \\
\text { programs }\end{array}$ & $\begin{array}{l}\text { Appropriate clinical } \\
\text { governance is required }\end{array}$ & $\begin{array}{r}\text { Table I. } \\
\text { EMS medical } \\
\text { direction/ambulance } \\
\text { service clinical } \\
\text { governance } \\
(2000-2016)\end{array}$ \\
\hline
\end{tabular}




\begin{tabular}{llll} 
Citation & Design & Country & Focus of paper \\
\hline Porter (2005) & Descriptive & UK & $\begin{array}{l}\text { Codes of practice for immediate } \\
\text { care doctors in NHS }\end{array}$
\end{tabular}

Major findings (strengths and weaknesses)

\section{6}

\begin{tabular}{|c|c|c|c|c|}
\hline $\begin{array}{l}\text { Walker } \\
\text { (2005) }\end{array}$ & Case study & Australia & $\begin{array}{l}\text { Paramedic response to } \\
\text { meningococcal septicemia }\end{array}$ & $\begin{array}{l}\text { Importance of strong clinical } \\
\text { governance processes in a } \\
\text { rural paramedic service }\end{array}$ \\
\hline $\begin{array}{l}\text { Tang and } \\
\text { Fabbri (2003) }\end{array}$ & Commentary & USA & Tactical EMS medical direction & $\begin{array}{l}\text { Continued development of } \\
\text { physician leadership is apparent }\end{array}$ \\
\hline Knott (2003) & $\begin{array}{l}\text { Telephone } \\
\text { survey of rural } \\
\text { EMS medical } \\
\text { directors }\end{array}$ & USA & $\begin{array}{l}\text { Identification of issues faced by } \\
\text { rural EMS }\end{array}$ & $\begin{array}{l}\text { Medical direction identified as } \\
\text { an issue with integration in } \\
\text { EMS seen as a possible } \\
\text { solution. Survey restricted to } \\
\text { medical directors }\end{array}$ \\
\hline Baker (2003) & Viewpoint & UK & $\begin{array}{l}\text { Implementation of clinical } \\
\text { governance }\end{array}$ & $\begin{array}{l}\text { Ambulance NHS Trusts may } \\
\text { find introducing clinical } \\
\text { governance necessary to } \\
\text { avoid potential system failure }\end{array}$ \\
\hline $\begin{array}{l}\text { Gausche-Hill } \\
\text { et al. (2003) }\end{array}$ & $\begin{array}{l}\text { Policy resource } \\
\text { and education } \\
\text { paper }\end{array}$ & USA & Guidance to medical directors & $\begin{array}{l}\text { Describes the development of } \\
\text { the federal EMS for Children } \\
\text { Program, the importance of } \\
\text { the integration, and discussed } \\
\text { the role of the emergency } \\
\text { physician in the Program }\end{array}$ \\
\hline $\begin{array}{l}\text { Benitez and } \\
\text { Pepe (2002) }\end{array}$ & $\begin{array}{l}\text { Descriptive } \\
\text { paper }\end{array}$ & USA & Trauma management & $\begin{array}{l}\text { Descriptive account of the role } \\
\text { of EMS medical directors in } \\
\text { the USA and Canada }\end{array}$ \\
\hline $\begin{array}{l}\text { Peterson } \\
(2002)\end{array}$ & Commentary & USA & Role of medical directors & $\begin{array}{l}\text { Derivative document that } \\
\text { provides a clear view on how } \\
\text { out-of-hospital EMS fits into } \\
\text { the overall emergency medical } \\
\text { system in the USA non-refereed }\end{array}$ \\
\hline $\begin{array}{l}\text { O’Meara et al. } \\
\text { (2001) }\end{array}$ & Descriptive & Australia & $\begin{array}{l}\text { Formation of a new model for the } \\
\text { recruitment and retention of } \\
\text { rural paramedic service medical } \\
\text { officers }\end{array}$ & $\begin{array}{l}\text { Recommended a more } \\
\text { integrated approach to the } \\
\text { paramedic service medical } \\
\text { officer role. Restricted to one } \\
\text { region in rural Australia }\end{array}$ \\
\hline $\begin{array}{l}\text { Stone et al. } \\
(2000)\end{array}$ & $\begin{array}{l}\text { Interviews of } \\
\text { medical } \\
\text { directors }\end{array}$ & USA & $\begin{array}{l}\text { Baseline of EMS medical } \\
\text { oversight in Maryland }\end{array}$ & $\begin{array}{l}\text { Increase in medical director } \\
\text { involvement required to meet } \\
\text { national job description }\end{array}$ \\
\hline $\begin{array}{l}\text { Robertson- } \\
\text { Steele et al. } \\
(2000)\end{array}$ & Evaluation & UK & $\begin{array}{l}\text { State of prehospital care and how } \\
\text { clinical governance can address } \\
\text { problems of fragmentation }\end{array}$ & $\begin{array}{l}\text { Makes recommendations to } \\
\text { improve quality and projects a } \\
\text { future course of action }\end{array}$ \\
\hline $\begin{array}{l}\text { Cone et al. } \\
(2000)\end{array}$ & $\begin{array}{l}\text { EMS medical } \\
\text { directors in } \\
\text { populous cities } \\
\text { surveyed. }\end{array}$ & USA & $\begin{array}{l}\text { Assess the availability of } \\
\text { physician medical directors for } \\
\text { field response }\end{array}$ & $\begin{array}{l}\text { Wide variability in the } \\
\text { availability, training and } \\
\text { scope of practice of physician } \\
\text { field response units }\end{array}$ \\
\hline
\end{tabular}

Table I.

A small number of medical directors in the USA dominate authorship of these papers with limited input from paramedics or other disciplines.

More recently, a Canadian conference paper by Fitzgerald examined the tension between the existing medical direction model and moves toward self-regulation through the lens of 
rhetorical genre theory; it charted the efforts of the Ontario Paramedic Association to argue the case for paramedic self-regulation against opposition from elements of the medical profession (Fitzgerald, 2014). It explicitly critiqued the place of medical direction in paramedic services, while a UK paper by McCann (Table II) examined the tension between the professionalization of paramedics and the strong position of power that medical directors and others exercise (McCann et al., 2013).

Literature on clinical governance within paramedic services was limited, with the seven papers located from the UK and Australia where paramedic services are components of integrated health systems. The papers from Webb et al. (2010) and Walker (2005) reported on cases where clinical governance was a positive factor in implementing changes in clinical practice, while one paper related to the clinical governance of immediate care doctors in the UK with only indirect relevance to paramedics (Porter, 2005). The remaining papers either called for the introduction of clinical governance (Mason et al., 2006; Nutbeam, 2011) or addressed the challenges of implementing it into fragmented and complex healthcare systems (Robertson-Steel et al., 2000; Baker, 2003). One noted that NHS Ambulance Trusts and other healthcare services need to strengthen existing clinical governance in order to deal with patients moving through different parts of the healthcare system (Baker, 2003).

There is little direct evidence supporting or refuting the effectiveness of clinical governance in paramedic services. However, it is difficult to argue that paramedic services should be managed and directed differently than other clinical delivery services such as those found in hospitals and other health services that have been steadily moving away from what is termed the "medical managed universal model" toward more complex and contested models of governance (Boyce, 2001). The traditional roles of medical directors in hospitals have been transformed to a position where medical directors no longer have untrammeled power over other health professions that have their own self-regulatory and registration structures (Kenny and Duckett, 2004).

\section{Paramedic clinical leadership}

The limited empirical literature related to both medical direction and clinical governance in paramedic services led to an extension of the search. When the search strategy was extended to "clinical leadership" combined with paramedic*, 20 additional papers meeting the inclusion criteria were found (Table II). The Canadian conference paper from Fitzgerald made a link between the limited progress on paramedic professional self-regulation and medical dominance (Fitzgerald, 2014).

In total, 12 papers related predominately to UK paramedic services, with six from Australia and New Zealand, and two from Canada. While a number of excellent studies in the literature addressed the quality and safety of paramedic services and practice (Mason et al., 2003, 2008; O'Hara et al., 2012; Cooke, 2006), they were not linked to clinical leadership, medical direction or clinical governance and were therefore excluded from further consideration.

The major themes identified in the papers were: paramedic professionalization, in particular the UK inspired paramedic professionalization project; paramedic registration or self-regulation developments; and the emergence of paramedic practitioner roles.

The concept of paramedics becoming clinical leaders in ambulance services formally emerged a decade ago in the UK following a call for improved opportunities for ambulance professionals to become clinical leaders using a Medical Leadership Competency Framework that encourages a diffused leadership model (Bradley, 2005; Marsh, 2009). Underlying the drive toward paramedic self-regulation and clinical leadership has been the evolution of advanced care paramedics, such as Critical Care Paramedics and Extended Care Paramedics in those developed countries where practitioner roles have been emerging. This evolution toward practitioner roles has been described in Australia (O'Meara, 2003) 


\begin{tabular}{llll} 
Citation & Design & Country & Focus of paper \\
\hline $\begin{array}{l}\text { Wankhade and } \\
\text { Wankhade }\end{array}$ & $\begin{array}{l}\text { Ethnographic } \\
\text { study - semi- } \\
\text { (2016) }\end{array}$ & UK & $\begin{array}{l}\text { Challenges for the paramedic } \\
\text { strofessionalization agenda } \\
\text { interviews and } \\
\text { obselated to increased work }\end{array}$ \\
intensity
\end{tabular}

Major findings (strengths and weaknesses)

$\begin{array}{ll}\text { Hodge (2014) } & \begin{array}{l}\text { Semi-structured } \\ \text { interviews with } \\ \text { consultant } \\ \text { paramedics }\end{array} \\ \text { Colbeck (2014) } & \text { Commentary }\end{array}$

UK

Place of consultant

Evidence for specialist paramedic roles. Highlighted the complexity of decisionmaking processes to minimize risk to patients Paramedic students are strong advocates of paramedic professionalism and support the need for regulation paramedics in an emerging clinical leadership Consultant paramedics are a framework key part of the clinical leadership team for the paramedic profession

Australia International comparisons of Authority to practice paramedic delegated practice regulations vary within the and authority to practice regulatory systems Anglo-American paramedic model. Delegated practice from physicians is not universal in modern paramedic services

\begin{tabular}{|c|c|c|c|}
\hline $\begin{array}{l}\text { Fitzgerald } \\
\text { (2014) }\end{array}$ & $\begin{array}{l}\text { Rhetorical genre } \\
\text { theory }\end{array}$ & Canada & $\begin{array}{l}\text { Efforts to introduce } \\
\text { paramedic self-regulation in } \\
\text { Ontario, Canada }\end{array}$ \\
\hline
\end{tabular}
Hidden values and Ontario, Canada assumptions (medical dominance) have delayed the adoption of a paramedic selfregulation model in Ontario

O'Meara (2014) Commentary Canada Examined self-regulation of paramedicine in terms of professional autonomy, job satisfaction and quality of care

Self-regulated paramedics

(Non-refereed) have the means to influence and ultimately to determine their own scopes of practice, set their own research agenda, and articulate a

Brady (2013) Commentary UK $\begin{aligned} & \text { Professional regulation of } \\ & \text { paramedics in the UK }\end{aligned}$
distinct professional identity Critical of the associated roles of the Health Care Professions Council and the Joint Royal Colleges Ambulance Liaison Committee

Lyndon-James Focus groups and Australia (2013) purposive interviews of

Considered whether National registration is an paramedicine is a profession essential component in gaining recognition by the broader healthcare industry members of the public

Tertiary education is synergistic to national registration and has the potential to enhance the quality of service delivery

$\begin{array}{llll}\begin{array}{l}\text { McCann } \text { et al. } \\ (2013)\end{array} & \begin{array}{l}\text { Ethnographic } \\ \text { study }\end{array} & \text { UK } & \begin{array}{l}\text { Paramedic } \\ \text { professionalization project }\end{array}\end{array}$
Overall impact of the project on working lives of paramedics is muted because of limited power over paramedic employers

Table II.

Paramedic selfregulation and clinical leadership (2000-2016) 


\begin{tabular}{ll} 
Citation & Design \\
\hline Stanley (2014) & $\begin{array}{l}\text { Mixed methods } \\
\text { comparative } \\
\text { study between } \\
\text { nurses and } \\
\text { paramedics } \\
\text { Commentary }\end{array}$
\end{tabular}

Country Focus of paper

Australia Compares the results of two studies, 6 years apart, into the attributes and characteristics of clinical leaders

UK

Future of the ambulance service in the UK
Major findings (strengths and weaknesses)

Both nurses and paramedics identify with leaders' values and follow them if reflected in the leaders' actions

Paramedics are a "disruptive technology" and improved paramedic education that focuses on clinical assessment and decisionmaking provides the best value for a positive impact on patients

First (2012) Review

UK

Transition of the paramedic workforce from a trade to a profession

Newton (2011) Commentary

UK

Walker et al. Letter (2010)

Sibson et al. Commentary

UK (2009)

Woollard (2009) Descriptive

UK

UK

Considers the future for paramedics in terms of extended practice

Announcing the launch of the Report of the National Steering Group on Clinical Leadership in the Ambulance Service The development of professionalism amongst paramedics is more likely to be a bottom-up evolution than a top-down revolution Position Statement from the College of Paramedics on the designation of paramedics There should be improved opportunities for career progression, with scope for ambulance professionals to become clinical leaders Discussion of establishment Appropriately trained of a National Steering Group clinical leaders with on Clinical Leadership

Explores influences on paramedic professional behaviors in the context of clinical governance and selfregulation

McPherson Systematic review New et al. (2006)

\section{Scott and \\ Carney (2004)}

Editorial

Doy and

Turner (2004)

Short report

UK

Zealand

Synthesis of evidence on extended roles for allied health, including paramedics

UK

Practitioner in emergency care $(\mathrm{PEC})$ concept

Development of emergency care practitioner $(\mathrm{ECP})$ program run by an Ambulance NHS Trust

O’Meara (2003) Soft systems methodology
Australia Development of a paramedic Paramedic practitioner practitioner model of care experience and influence are needed in paramedic services How collective behavior and beliefs of paramedics are viewed externally will determine whether paramedicine is seen as a profession

Critical that most of the work on extended scopes of practice for paramedics have focused on specific skill acquisition Identified problems implementing practitioner model

Cultural change and development of an infrastructure to support new clinical decision-making and referral pathways is vital to ensure the success of ECPs

model has potential is in rural settings
Clinical leadership in paramedic services

259 
IJHG

22,4

260

and the UK (Scott and Carney, 2004; Doy and Turner, 2004) where implementation challenges were identified, and more critically examined in New Zealand by McPherson $\mathrm{et}$ al. (2006) who criticized the concentration on skill acquisition for extended care paramedics.

Following the UK Report of the National Steering Group on Clinical Leadership in the Ambulance Service in 2009 (Marsh, 2009) discussions began to address questions of governance, professionalization of the workforce and paramedic leadership. A group of paramedic leaders have raised these inter-related issues through several publications in UK paramedic journals (Sibson et al., 2009; Walker et al., 2010; Newton, 2011; Woollard, 2009). Progress on the professionalization project has been reported further by First (2012), Newton (2012), McCann et al. (2013) and most recently Wankhade and Wankhade (2016) who supported calls for the paramedic services to evolve into mobile healthcare providers in response to the demands of the modern world (Newton and Harris, 2015). More broadly, Hodge (2014) and Stanley (2014) examined paramedic clinical leadership characteristics in the UK and Australia.

There have been optimistic calls for paramedic professionalization in Australia and Canada where successful professionalization programs have been associated with baccalaureate education being available and mandated for entry-level paramedics, combined with paramedic professional registration or self-regulation (O'Meara, 2014; Brady, 2013; Colbeck, 2014; Lyndon-James, 2013; Williams et al., 2015). The concept of paramedics developing more autonomy and higher levels of clinical judgment and decision making is an important component of the collective vision in these papers (O'Meara, 2014; Woollard, 2009). It is notable that there are now textbooks available that focus on paramedic clinical leadership and the development of paramedic clinical practice (Blaber and Harris, 2014; Johnson et al., 2015).

\section{Future directions}

While this narrative review identified more comment, discussion and debate than strong evidence, it did provide an opportunity to synthesize the available information through the consideration of some key questions. The medical direction, clinical governance and paramedic clinical leadership models are grappling with the challenges of health system fragmentation and efforts to integrate paramedic services into health systems. Broad contextual differences lie in the degree of integration across different health systems and the emergence of paramedicine as a distinct health profession.

Despite its long history in North America, there is a lack of strong evidence supporting paramedic service medical direction. In particular, there are no comparative studies with mature paramedic services operating without medical direction that might demonstrate clinical outcomes that are as good as or superior to the medically led paramedic services in North America. On the other hand, there remains limited evidence that supports the superiority of the clinical governance approach to leading, monitoring and managing the quality and safety systems in paramedic services.

\section{Quality and safety}

In the USA sourced literature on medical direction, the achievement of quality care and patient safety is used as a justification for medicine's power to proclaim on the practice rights of other occupations, including paramedicine (McMurray, 2010). Detractors describe this traditional position of medicine as the guardians of quality and safety as either medical dominance or medical paternalism (McCann et al., 2013; Fitzgerald, 2014; Willis, 2006). In the wider literature, this strong delineation of traditional professional boundaries is being challenged; for instance, in emergency medicine the concept of introducing models of care using a wide range of advanced (autonomous) non-medical practitioners in being considered in response to a shortage of physicians (Sujan et al., 2017). In North America, Bourgeault and Mulvale (2006) 
argue that the embeddedness of medical dominance undermines efforts to establish more collaborative models of health care, while Kenny and Duckett (2004) in Australia describe the erosion of medicine's power and dominance. The argument for medical direction in paramedic services is greatly weakened by the absence of strong evidence that the model is associated with improved outcomes (Hesselink et al., 2016).

The papers from South Korea (Kim et al., 2015; Lee and Kim, 2015) implied that medical direction was needed because their EMS personnel lack the education to adequately assess patients or make decisions to institute some clinical interventions without direction. Supporting this argument, the paramedic literature from developed countries such as the UK, Australia and New Zealand, take the position that the solution to poor decision-making is through paramedic professionalization using extended educational preparation and stronger professional accountability.

Fitzgerald is an articulate voice in relation to paramedicine clinical governance in North America, where she argues that the lack of progress on paramedic self-regulation in parts of Canada is a result of continued medical dominance (Fitzgerald, 2014). In the UK, McCann et al. (2013) argue along similar lines that, paramedics have "[...] weak levels of formal autonomy, because most tasks are pre-structured by other professionals," through devices such as the development of clinical protocols or clinical practice guidelines with limited input of practicing paramedics.

\section{Health system integration}

In the UK and other countries with well-integrated health systems, there has been a weakening of medical dominance over other health professions through the widespread adoption of clinical governance systems that rely on the combined logic of professionalism and managerialism (McCann et al., 2013). This theme is evident in discussions in the literature about how clinical governance can have a positive impact on the quality and safety of paramedic practice, especially in regard to new emerging roles such as Emergency Care Practitioners to meet the needs of patients, the community and stressed health systems (O'Hara et al., 2012; Mason et al., 2008).

In many of these countries with relatively well-integrated health systems and paramedic services, clinical governance is a well-established part of paramedic services, with senior paramedic managers assigned responsibility and accountability for the overall leadership, monitoring and management of clinical services through established clinical governance frameworks that emphasize the shared responsibility for clinical governance and the delivery of high quality care (Ambulance Tasmania, 2012; Thompson and Playfoot, 2010).

Some of these efforts to better integrate paramedic services with the health, aged care and social service systems have been criticized for their "top down" approach, with practising paramedics unable to make the leap to full professional status because of their inability to achieve a sense of autonomy and discretion over their everyday work (McCann et al., 2013). There has been a persistence of "blue-collar professionalism" amongst practicing paramedics (Metz, 1981) that has been attributed to the dominance of managerialism and the relative weakness of the paramedicine profession to assert sufficient power despite some success in taking on the trappings of professionalism (McCann et al., 2013; Woollard, 2006; Brady, 2013).

\section{Professionalization and leadership}

Another theme in the literature was the growing professionalization of the paramedic workforce and the accompanying shift in their sources of leadership. This theme largely emanates from the UK and Australia where the professionalization of the paramedic workforce is well advanced, with considerable progress having been made toward the professional regulation of paramedics through State sanctioned registration of paramedics
Clinical
leadership in
paramedic
services

261 
IJHG

22,4

and the almost complete transfer of paramedic education into their respective higher education systems (O’Brien et al., 2013; Willis et al., 2010; Brooks et al., 2015). In contrast, there remains is a paucity of baccalaureate paramedic programs in North America (Alexander et al., 2009; Barisshansky and Kirkwood, 2010).

A study on the perception of clinical leadership in St John Ambulance in Western Australia (Stanley et al., 2012, 2014) is instructive. The paramedic component of this research took place following a government report into the same paramedic service outlining significant clinical governance failures despite having a medical director (Joyce, 2010). These papers and reports argued that clinical leadership is not the sole responsibility or domain of the medical director; the strong message was that paramedics look toward their senior peers as role models and clinical leaders. They concluded that having a capable and skilled medical director without a strong clinical governance framework is a risk that needs to be addressed through the establishment of a classic clinical governance framework with shared responsibility for clinical safety and quality at an organizational level (Joyce, 2010).

In England, paramedicine has moved further toward self-regulation than in other comparable countries. Wankhade and Wankhade (2016), and Newton and Harris (2015) argue that paramedic services and paramedics are in a transitionary period between the traditional treat and transport paradigm and the full emergence of paramedics as professionalized providers of mobile healthcare in an integrated health system. Underlying these arguments is the observation that "[...] life-threatening conditions no longer represent the core demand for most ambulance [paramedic] services" (p. 83), with paramedics more likely to be delivering primary care such as wound management, near patient testing and offering referral options to patients (Newton and Harris, 2015). For these changes in the operational model to be successful, changes in paramedic education, relationships with other health professionals and clinical governance arrangements are necessary.

Recently in the USA, questions have been raised by a medical director about the appropriate relationships between paramedics, their medical director and the physicians of patients using mobile integrated healthcare systems (Richmond, 2016). These questions included how to co-ordinate two sets of medical directives, authorization of protocols and assign responsibility for quality assurance. In countries where paramedics work as autonomous, self-regulated health professionals they would consider the clinical situation, consult with other health professionals as indicated (such as the patient's own physician), and then use their own clinical judgment to act in the best interests of the patient.

\section{Conclusions}

While the strategies designed to maintain the quality and safety of paramedic services and paramedic clinical practice in the Anglo-American model have differing underpinnings, the literature cuts across three inter-related themes. These themes of quality and safety, health system integration, and professionalization and leadership are not unique to paramedicine, with other emerging health professions having travelled the same journey from professional subservience to differing degrees of professional autonomy through their "licence to practice" and a "mandate" to define their own practice and conduct (Currie et al., 2003; Dingwall, 2008; Allan, 1997). Paramedics and paramedic services in many developed countries show a preference for professional regulatory boards and clinical governance frameworks to produce high quality services. In these countries, paramedicine is evolving into an autonomous, self-regulated health profession. Paramedics continuing to practice as a companion profession to medicine under a delegated practice model is inconsistent with this vision.

In light of the findings of this narrative synthesis, paramedics and other stakeholders need to consider whether this apparent divergence within the Anglo-American model is 
permanent and inevitable. It might be possible to reconcile the tensions between medical dominance and paramedic professionalism through strategic interventions, such as stronger educational structures and self-regulation regimes.

\section{References}

Alexander, M., Weiss, S., Braude, D., Ernst, A.A. and Fullerton-Gleason, L. (2009), "The relationship between paramedics' level of education and degree of commitment", The American Journal of Emergency Medicine, Vol. 27 No. 7, pp. 830-837.

Allan, D. (1997), “The nursing-medical boundary: a negotiated order?”, Sociology of Health and Illness, Vol. 19 No. 4, pp. 498-520.

Al-Shaqsi, S.Z.K. (2010), "Models of international emergency medical service (EMS) systems", Oman Medical Journal, Vol. 25 No. 4, pp. 320-323.

Ambulance Service of New South Wales (2015), "Organisational structure", available at: www. ambulance.nsw.gov.au/about-us/Organisational-Structure.html (accessed October 6, 2017).

Ambulance Tasmania (2012), "Clinical governance framework 2012", in Department of Health and Human Services (Ed.), Tasmanian Government, Hobart, pp. 1-19, available at: www.dhhs.tas. gov.au/ambulance/welcome_to_tasmanian_ambulance_and_health_transport_service/ publications? $\mathrm{a}=107015$ (accessed October 6, 2017).

Amey, B., Straub, E. and Harrison, E. (1978), "Medical control of paramedic services", Emergency Medical Services, Vol. 7 No. 4, pp. 20-22.

Baker, M.R. (2003), "Accountability and responsibility: clinical governance beyond the institution", Clinical Governance: An International Journal, Vol. 8 No. 4, pp. 288-289.

Barisshansky, R.M. and Kirkwood, S. (2010), "The four-year plan. Getting a bachelor's degree can open a whole new world for EMS professionals", Journal of Emergency Medical Services, Vol. 39 No. 5 , pp. 38-41.

Barnett, A., Segree, W. and Matthews, A. (2006), "The roles and responsibilities of physicians in pre-hospital emergency medical services: a Caribbean perspective”, The West Indian Medical Journal, Vol. 55 No. 1, pp. 52-55.

Bass, R.R., Lawner, B., Lee, D. and Nable, J.V. (2015), "Medical oversight of EMS systems”, in Cone, D.C., Brice, J.H., Delbridge, T.R. and Myers, B. (Eds), Emergency Medical Services: Clinical Practice and Systems Oversight, John Wiley \& Sons, pp. 69-84.

Becknell, J. (1997), "The benevolent dictator. A new breed of medical director", Journal of Emergency Medical Services, Vol. 22 No. 7, p. 36.

Benitez, F.L. and Pepe, P.E. (2002), "Role of the physician in prehospital management of trauma: North American perspective", Current Opinion in Critical Care, Vol. 8 No. 6, pp. 551-558.

Blaber, A. and Harris, G. (2014), Clinical Leadership for Paramedics, McGraw-Hill Education, Milton Keynes.

Bourgeault, I.L. and Mulvale, G. (2006), "Collaborative health care teams in Canada and the USA: confronting the structural embeddedness of medical dominance", Health Sociology Review, Vol. 15 No. 5, pp. 481-495.

Boyce, R.A. (2001), "Organisational governance structures in allied health services: a decade of change", Australian Health Review, Vol. 24 No. 1, pp. 22-36.

Bradley, P. (2005), Taking Healthcare to the Patient - Transforming NHS Ambulance Services, Department of Health, London.

Brady, M. (2013), "Health and care professions council: protecting whom?", Journal of Paramedic Practice, Vol. 5 No. 5, pp. 246-247.

Brennan, N.M. and Flynn, M.A. (2013), "Differentiating clinical governance, clinical management and clinical practice”, Clinical Governance: An International Journal, Vol. 18 No. 2, pp. 114-131. 
IJHG

22,4

Brooks, I.A., Cooke, M., Spencer, C. and Archer, F. (2015), "A review of key national reports to describe the development of paramedic education in England (1966-2014)", Emergency Medicine Journal, Vol. 33 No. 12 , pp. $876-881$.

Bury, G. (2005), "Pre-hospital emergency care in Ireland", Emergency Medicine Journal, Vol. 22 No. 12, p. 893.

Busko, J., Margolis, G.S. and Politis, J. (2006), "Professional medical direction. It's not too much to ask", Journal of Emergency Medical Services, Vol. 31 No. 3, pp. 92-99.

Colbeck, M. (2014), “The Australian consultant paramedic: a future direction?”, Australasian Journal of Paramedicine, Vol. 11 No. 2.

Committee on the Future of Emergency Care in the United States Health System (2007), Emergency Medical Services at the Crossroads, National Academies Press, Washington, DC.

Cone, D., Brice, J.H., Delbridge, T.R. and Myers, J.B. (2014), Emergency Medical Services: Clinical Practice and Systems Oversight, 2 Volume Set, John Wiley \& Sons.

Cone, D.C., Wydro, G.C. and Mininger, C.M. (2000), "Physician field response: a national survey", Prehospital Emergency Care, Vol. 4 No. 3, pp. 217-221.

Cooke, M. (2006), "Emergency care practitioners: a new safe effective role?", Quality and Safety in Health Care, Vol. 15 No. 6, p. 387.

Council of Ambulance Authorities (2010), Guidelines for the Assessment and Accreditation of Entry-level Paramedic Education Programs, Council of Ambulance Authorities Inc., Adelaide.

Cunningham, C.A., Wesley, K., Peterson, T.D., Alcorta, R., Kupas, D.F., Nelson, J.A., Taillac, P. and Upchurch, J. (2010), "The role of state medical direction in the comprehensive emergency medical services system: a resource document”, Prehospital Emergency Care, Vol. 14 No. 3, pp. 404-411.

Currie, G., Finn, R. and Martin, G. (2003), “Accounting for the 'dark side' of new organizational forms: the case of health care professions", Human Relations, Vol. 61 No. 4, pp. 539-564.

Cushman, J.T., Zachary Hettinger, A., Farney, A. and Shah, M.N. (2010), "Effect of intensive physician oversight on a prehospital rapid-sequence intubation program", Prehospital Emergency Care, Vol. 14 No. 3, pp. 310-316.

Dean, S.J. (2004), A Study of the Political and Economic Obstacles to Improvement of Emergency Medical Service Systems, University of Maryland Baltimore County, Baltimore, MD.

Delbridge, T.R., Bailey, B., Chew, J.L., Conn, A.K.T., Krakeel, J.J., Manz, D., Miller, D.R., O’Malley, P.J., Ryan, S.D., Spaite, D.W., Stewart, R.D., Suter, R.E. and Wilson, E.M. (1998), "EMS agenda for the future: where we are ... where we want to be", Annals of Emergency Medicine, Vol. 31 No. 2, pp. 251-263.

Dingwall, R. (2008), Essays on Prefessions, Ashgate Publishing Limited, Aldershot.

Doy, R. and Turner, K. (2004), "The giraffe: the emergency care practitioner; fit for purpose? The East Anglian experience”, Emergency Medicine Journal, Vol. 21 No. 3, pp. 365-366.

Eburn, M. (2014), "What is a paramedic's 'authority to practice??, Australian Emergency Law (Online).

Eburn, M. and Bendall, J.C. (2010), "The provision of ambulance services in Australia: a legal argument for the national registration of paramedics", Journal of Emergency Primary Health Care, Vol. 8 No. 4.

Ferko, J. (1987), "Why EMS needs physicians. Physician's role in prehospital EMS", Journal of Emergency Medical Services, Vol. 12 No. 9, p. 51.

First, S. (2012), "From trade to profession-the professionalisation of the paramedic workforce", Journal of Paramedic Practice, Vol. 4 No. 7, pp. 378-381.

Fitzgerald, S. (2014), "More than just ambulance drivers: a genre struggle for professional recognition", 6th Annual Conference of the Canadian Association for the Study of Discourse and Writing, Brock University, St Catharines.

Frank, M. (1984), "Medical director vs fire chief", Journal of Emergency Medical Services, Vol. 9 No. 6, pp. 46-55. 
Freeman, T., Millar, R., Mannion, R. and Davies, H. (2016), "Enacting corporate governance of healthcare safety and quality: a dramaturgy of hospital boards in England", Sociology of Health \& Illness, Vol. 38 No. 2, pp. 233-251.

Garza, A. and Mitchell, E. (2012), "Handbook for EMS medical directors", in Federal Emergency Management Agency (FEMA) (Ed.), US Department of Homeland Security, Washington, DC.

Gausche-Hill, M., Johnson, R.W., Warden, C.R., Brennan, J.A., Baren, J., Cordle, R.J., Dietrich, A., Gold, C., Johnson, R. and Knazik, S. (2003), "The role of the emergency physician in emergency medical services for children”, Annals of Emergency Medicine, Vol. 42 No. 2, pp. 206-215.

Golin, C. (1980), "How MDs would improve emergency medical care in flight", American Medical News, Vol. 23 No. 9, p. 9.

Halligan, A. and Donaldson, L. (2001), "Implementing clinical governance: turning vision into reality", British Medical Journal, Vol. 322 No. 7299, p. 1413.

Health and Care Professions Council (2015), Standards of Education and Training, HCPC-UK, London.

Henry, M. and Stapleton, E. (1985), "EMTs and medical control", A Journal of Emergency Medical Services, Vol. 10 No. 1, pp. 32-34.

Hesselink, G., Berben, S., Beune, T. and Schoonhoven, L. (2016), "Improving the governance of patient safety in emergency care: a systematic review of interventions", BMJ Open, Vol. 6 No. 1.

Hodge, A. (2014), "Developing leadership in the UK's ambulance service: a review of the consultant paramedic role", Journal of Paramedic Practice, Vol. 6 No. 3, pp. 138-146.

Johnson, M., Boyd, L., Grantham, H. and Eastwood, K. (2015), Paramedic Principles and Practice ANZ: A Clinical Reasoning Approach, Harcourt Publishers Group, Chatswood.

Joyce, G. (2010), “St John ambulance inquiry - implementation of recommendations", in Department of Health (Ed.), Government of Western Australia, Perth.

Kenny, A. and Duckett, S. (2004), "A question of place: medical power in rural Australia”, Social Science \& Medicine, Vol. 58 No. 6, pp. 1059-1073.

Kim, J.M., Park, J.H., Hyeon, S.Y., Sin, Y.S., Lee, D.W., Kim, J.Y., Kim, J.Y., Cho, H.J. and Moon, S.W. (2015), "Implementation of a direct medical direction system for 119 EMS providers and expansion of scope of practices under the indirect protocols-experience in Gyunggi province", Journal of the Korean Society of Emergency Medicine, Vol. 26 No. 4, pp. 276-285.

Knott, A. (2003), "Emergency medical services in rural areas: the supporting role of state EMS agencies", The Journal of Rural Health, Vol. 19 No. 4, pp. 492-496.

Krohmer, J.R. (1997), “The patient's best advocate”, Journal of Emergency Medical Services, July, pp. $43-44$.

Lee, S.K. and Kim, W.J. (2015), "Recognition of medical direction in emergency medical service personnel in Jeju", International Journal of Bio-Science and Bio-Technology, Vol. 7 No. 6, pp. $75-84$.

Lyndon-James, P. (2013), "Striving for the professionalisation of Australian paramedics”, International Paramedic Practice, Vol. 3 No. 3, pp. 74-78.

McCann, L., Granter, E., Hyde, P. and Hassard, J. (2013), "Still blue-collar after all these years? An ethnography of the professionalization of emergency ambulance work", Journal of Management Studies, Vol. 50 No. 5, pp. 750-776.

McMurray, R. (2010), "The struggle to professionalize: an ethnographic account of the occupational position of advanced nurse practitioners", Human Relations, Vol. 64 No. 6, pp. 801-822.

McPherson, K., Kersten, P., George, S., Lattimer, V., Breton, A., Ellis, B., Kaur, D. and Frampton, G. (2006), "A systematic review of evidence about extended roles for allied health professionals", Journal of Health Services Research \& Policy, Vol. 11 No. 4, pp. 240-247.

Marsh, A. (2009), Report of the National Steering Group on Clinical Leadership in the Ambulance Service, NHS, London. 
IJHG

22,4

Mason, S., Wardrope, J. and Perrin, J. (2003), "Developing a community paramedic practitioner intermediate care support scheme for older people with minor conditions”, Emergency Medicine Journal Online, Vol. 20, pp. 196-198.

Mason, S., Knowles, E., Freeman, J. and Snooks, H. (2008), "Safety of paramedics with extended skills", Academic Emergency Medicine, Vol. 15, pp. 607-612.

Mason, S., Coleman, P., O'Keeffe, C., Ratcliffe, J. and Nicholl, J. (2006), "The evolution of the emergency care practitioner role in England: experiences and impact", Emergency Medicine Journal, Vol. 23 No. 6, pp. 435-439.

Matera, P.A. (1997), "Doc on the street: another view”, Journal of Emergency Medical Services, July, pp. 48-49.

Metz, D. (1981), Running Hot: Structure and Stress in Ambulance Work, ABT Books, Cambridge, MA.

Michael, J. and French, A. (2000), "EMS education agenda for the future: a vision for the future of EMS education", Annals of Emergency Medicine, Vol. 35 No. 6, pp. 623-625.

Millin, M.G., Brown, L.H., Craven, C.K., Hawkins, S.C., Tan, D.K., Piazza, G.M., Cone, D.C. and Sattin, R.W. (2011), "Evolution of the literature identifying physicians' roles in leadership, clinical development, and practice of the subspecialty of emergency medical services", Prehospital and Disaster Medicine, Vol. 26 No. 1, pp. 49-64.

Munk, M.-D., White, S.D., Perry, M.L., Platt, T.E., Hardan, M.S. and Stoy, W.A. (2009), "Physician medical direction and clinical performance at an established emergency medical services system”, Prehospital Emergency Care, Vol. 13 No. 2, pp. 185-192.

National Research Council, Committee on Trauma and National Research Council, Committee on Shock (1971), Accidental Death and Disability: The Neglected Disease of Modern Society, National Academies, Washington, DC.

National Rural Health Association (1997), Rural and Frontier Emergency Medical Services Toward the Year 2000, National Rural Health Association, Washington, DC.

Newman, B. (1982), "EMS medical control: doctor-shoppers need not apply", Journal of Emergency Medical Services, Vol. 7 No. 11, p. 43.

Newton, A. (2011), "Specialist practice for paramedics: a bright future", Journal of Paramedic Practice, Vol. 3 No. 2, pp. $58-61$.

Newton, A. (2012), "The ambulance service: the past, present and future", Journal of Paramedic Practice, Vol. 4 No. 6, pp. 365-368.

Newton, A. and Harris, G. (2015), "Leadership and system thinking in the modern ambulance service", in Wankhade, P. and Mackway-Jones, K. (Eds), Ambulance Services: Leadership and Management Perspectives, Springer International Publishing, Cham, pp. 81-93.

Nicholson, W.C. (1997), "Liability risks: fact or fiction?", Journal of Emergency Medical Services, July, pp. $44-47$.

Nutbeam, T. (2011), "Clinical governance and prehospital care in the UK", Emergency Medicine Journal, Vol. 28 No. 2, pp. 91-92.

O’Brien, K., Moore, A., Dawson, D.A. and Hartley, P.R. (2013), “An Australian story: paramedic education and practice in transition", Australasian Journal of Paramedicine, Vol. 10 No. 4.

O'Hara, R., O'Keeffe, C., Mason, S., Coster, J.E. and Hutchinson, A. (2012), "Quality and safety of care provided by emergency care practitioners”, Emergency Medicine Journal, Vol. 29 No. 4, pp. 327-332.

O'Meara, P. (2003), "Would a prehospital practitioner model improve patient care in rural Australia?”, Emergency Medicine Journal, Vol. 20, pp. 199-203.

O’Meara, P. (2014), "Paramedic self-regulation and professional autonomy", Canadian Paramedicine, No. 5, pp. 18-19.

O'Meara, P., Strasser, R., Marrow, A. and Leleivre, P. (2001), "An integrated approach to the role of the ambulance medical officer in rural Australia", Pre-Hospital Immediate Care, Vol. 5 No. 1, pp. 24-26. 
Peterson, T.D. (2002), "Commentary: medical direction for out-of-hospital emergency medical services", Annals of Emergency Medicine, Vol. 39 No. 4, pp. 451-452.

Polsky, S., Krohmer, J., Maningas, P., Mcdowell, R., Benson, N. and Pons, P. (1993), "Guidelines for medical direction of prehospital EMS", Annals of Emergency Medicine, Vol. 22 No. 4, pp. 742-744.

Popay, J., Roberts, H., Sowden, A., Petticrew, M., Arai, L. and Rodgers, M. (2005), Guidance on the Conduct of Narrative Synthesis in Systematic Reviews, Lancaster University, Lancaster, available at: www.lancs.ac.uk/shm/research/nssr/index.htm

Porter, K. (2005), "Code of practice between immediate care doctors and ambulance NHS trusts", Emergency Medicine Journal, Vol. 22 No. 11, pp. 822-822.

Pretorius, A., Karunaratne, N. and Fehring, S. (2015), "Australian physiotherapy workforce at a glance: a narrative review", Australian Health Review, Vol. 40 No. 4, pp. 438-442.

Reynolds, L. (2009), “Contextualising paramedic culture”, in O’Meara, P. and Grbich, C. (Eds), Paramedics in Australia: Contemporary Challenges of Practice, 1st ed., Pearson Education Australia, Sydney, pp. 37-52.

Richmond, N. (2016), "Medical direction for MIH-CP programs", EMS World Expo, EMS World, New Orleans, LA.

Robertson-Steel, I., Edwards, S. and Gough, M. (2000), "Clinical governance in pre-hospital care", Journal of the Royal Society of Medicine, Vol. 94 No. S39, pp. 38-42.

Scott, J. and Carney, C. (2004), "Emergency care practitioners: important developments in the delivery of emergency care”, Emergency Medicine Journal, Vol. 21, pp. 273-274.

Sibson, L., Walker, A. and Marsh, A. (2009), "Providing world-class care through clinical leadership", Journal of Paramedic Practice, Vol. 1 No. 10, pp. 432-433.

Slifkin, R.T., Freeman, V.A. and Patterson, P.D. (2009), "Designated medical directors for emergency medical services: recruitment and roles", The Journal of Rural Health, Vol. 25, pp. 392-398.

Spigelman, A.D. and Rendalls, S. (2015), "Clinical governance in Australia”, Clinical Governance: An International Journal, Vol. 20 No. 2, pp. 56-73.

Stanley, D. (2014), "Clinical leadership characteristics confirmed", Journal of Research in Nursing, Vol. 19 No. 2, pp. 118-128.

Stanley, D., Cuthbertson, J. and Latimer, K. (2012), "Perceptions of clinical leadership in the St John ambulance service in WA", Response, Vol. 39 No. 1, pp. 31-37.

Stone, R.M., Seaman, K.G. and Bissell, R.A. (2000), "A statewide study of EMS oversight: medical director characteristics and involvement compared with national guidelines”, Prehospital Emergency Care, Vol. 4 No. 4, pp. 345-351.

Studnek, J.R., Fernandez, A.R., Margolis, G.S. and O'connor, R.E. (2009), "Physician medical oversight in emergency medical services: where are we?", Prehospital Emergency Care, Vol. 13 No. 1, pp. 53-58.

Sujan, M., Howard-Franks, H., Swann, G., Soanes, K., Pope, C., Crouch, R., Staniszewska, S., Maxwell, E., Huang, H. and Cooke, M. (2017), "Impact of advanced autonomous non-medical practitioners in emergency care: protocol for a scoping study", BMJ Open, Vol. 7 No. 1, p. e014612.

Tang, N. and Fabbri, W. (2003), "Medical direction and integration with existing EMS infrastructure", Advanced Emergency Nursing Journal, Vol. 25 No. 4, pp. 326-332.

Thompson, F. and Playfoot, B. (2010), Clinical and Quality Governance Strategy 2010-2012, South Central Ambulance Service NHS Trust, Bicester.

Timmermanna, A., Russoa, S.G. and Hollmann, M.W. (2008), "Paramedic versus emergency physician emergency medical service: role of the anesthesiologist and the European versus the Anglo-American concept", Current Opinion in Anesthesiology, Vol. 21 No. 2, pp. 222-227.

US Congress (2016), "Protecting patient access to emergency medications Act of 2016", 114th Congress, 2nd Session ed. 
IJHG

22,4

US National Highway Traffic Safety Administration (1996), Emergency Medical Services Agenda for the Future, National Highway Traffic Safety Administration, Washington, DC.

Walker, A., Sibson, L. and Marsh, A. (2010), "Clinical leadership in the ambulance service", Emergency Medicine Journal, Vol. 27 No. 6, p. 490.

Walker, T. (2005), "Pre-hospital paramedic administration of ceftriaxone for suspected meningococcal septicaemia in Victoria, Australia", Australasian Journal of Paramedicine, Vol. 3 Nos 1-2.

Wankhade, P. and Wankhade, P. (2016), "Staff perceptions and changing role of pre-hospital profession in the UK ambulance services: an exploratory study", International Journal of Emergency Services, Vol. 5 No. 2, pp. 126-144.

Webb, V., Stark, M., Cutts, A., Tait, S., Randle, J. and Green, G. (2010), "One model of healthcare provision lessons learnt through clinical governance", Journal of Forensic and Legal Medicine, Vol. 17 No. 7, pp. 368-373.

Wilkes, G. (2010), "Chapter 11, EMS medical directors”, in Tintinalli, J., Cameron, P. and Holliman, C. (Eds), EMS: A Practical Global Guidebook, People's Medical Publishing House, Shelton, CT, pp. 133-142.

Williams, B., Fielder, C., Strong, G., Acker, J. and Thompson, S. (2015), “Are paramedic students ready to be professional? An international comparison study", International Emergency Nursing, Vol. 23 No. 2, pp. 120-126.

Willis, E. (2006), "Introduction: taking stock of medical dominance", Health Sociology Review, Vol. 15 No. 5, pp. 421-431.

Willis, E., Williams, B., Brightwell, R., O’Meara, P. and Pointon, T. (2010), "Road-ready paramedics and the supporting sciences curriculum", Focus on Health Professional Education, Vol. 11 No. 2, pp. 1-13.

Woollard, M. (2006), "The role of the paramedic practitioner in the UK", Journal of Emergency Primary Health Care, Vol. 4 No. 1.

Woollard, M. (2009), "Professionalism in UK paramedic practice", Journal of Emergency Primary Health Care, Vol. 7 No. 4.

\section{Corresponding author}

Peter O’Meara can be contacted at: p.omeara@latrobe.edu.au

For instructions on how to order reprints of this article, please visit our website:

www.emeraldgrouppublishing.com/licensing/reprints.htm

Or contact us for further details: permissions@emeraldinsight.com 